\title{
Long-term Results of Radiotherapy in Patients with Chronic Palmo-plantar Eczema or Psoriasis
}

\author{
Marcin Sumila', Markus Notter', Peter Itin², Stephan Bodis', Guenther Gruber ${ }^{1}$
}

\begin{abstract}
Background and Purpose: Radiotherapy (RT) is well accepted for therapy-refractory palmo-plantar eczema or psoriasis, despite of lacking evidence regarding beneficial long term effects. Furthermore, the optimal irradiation dose is unknown. We evaluated the outcome of RT with two different RT single/total dose (SD/TD) treatment policies.

Patients and Methods: 28 consecutive patients with therapy-refractory eczema $(n=22)$ or psoriasis $(n=6)$ of palms and/or soles were irradiated twice a week either with a $D_{\max }$ SD of 1 Gy (6/98-5/03; median TD: 12 Gy) or 0.5 Gy (6/03-7/04; median TD: $5 \mathrm{~Gy}$ ). Median age was 52 years (27-71), median follow-up 20 months (4-76). Totally 88 regions were treated, 49 with $1 \mathrm{~Gy}$, 39 with 0.5 Gy SD. Eight different symptoms were scored from 0 (absent) -3 (severe), giving a possible sum score of $0-24$. Patients' rating of RT result was also documented (worse/stable/better/complete remission).

Results: The sum score was 15 (6-23) before RT, $2(0-16)$ at the end of RT, and $1(0-21)$ at last follow-up, respectively. The improvement was highly significant in both treatment regimens. Better or complete remission by the patients were reported in 44 and 39 (= 83 out of 88 ) localisations, that was often stable during the follow-up. $5(6 \%)$ regions in $3(11 \%)$ patients didn't benefit from RT.

Conclusion: RT reveals excellent results in palmo-plantar eczema or psoriasis. We recommend a SD of 0.5 Gy twice a week up to a TD of 4-5 Gy.
\end{abstract}

Key Words: Palmo-plantar eczema · Psoriasis · Radiotherapy dose

Strahlenther Onkol 2008;184:218-23

DOI $10.1007 / \mathrm{s} 00066-008-1788-4$

\section{Langzeitergebnisse der Radiotherapie bei Patienten mit palmoplantaren Ekzemen oder Psoriasis}

Hintergrund und Ziel: Die Radiotherapie (RT) ist eine etablierte Therapiemethode bei therapierefraktären palmoplantaren Ekzemen und Psoriasis (Tabelle 1), trotz fehlender Evidenz betreff Langzeitresultaten. Des Weiteren bleibt die optimale Dosierung unklar. Wir stellen die Resultate der RT mit zwei verschiedenen Dosierungskonzepten (Einzel-/Gesamtdosis, ED/GD) vor.

Patienten und Methodik: 28 konsekutive Patienten mit therapierefraktären Ekzemen oder Psoriasis der Hände und/oder der Füße wurden zwei Mal pro Woche entweder mit ED 1 Gy (von Juni 1998 - Mai 2003; mediane GD: 12 Gy) oder mit ED 0,5 Gy (von Juni 2003 - Juli 2004; mediane GD: 5 Gy) bestrahlt. Das Alter der Patienten betrug median 52 Jahre (27-71), die Beobachtungszeit median 20 Monate (4-76). Insgesamt wurden 88 Regionen bestrahlt, 49 mit ED 1 Gy und 39 mit ED 0,5 Gy. Acht verschiedene Symptome wurden jeweils zwischen 0 (symptomfrei) und 3 (schwer) eingestuft (Tabelle 2), was in einem Summen-Score von 0 bis 24 resultierte. Ebenfalls wurde die Beurteilung des Therapieergebnisses durch die Patienten selbst (schlechter, unverändert, besser, komplette Remission) dokumentiert.

Ergebnisse: Der Summen-Score vor der RT betrug median 15 (6-23), bei RT-Abschluss 2 (0-16) und bei der letzten Nachkontrolle 1 (0-21) (Tabelle 3, Abbildung 1). Ein hochsignifikanter Unterschied zum Ausgangsbefund konnte für beide Behandlungsschemata dokumentiert werden (Tabelle 4). In 44 bzw. 39 (= 83 von 88) Lokalisationen haben die Patienten das Ergebnis bei RT-Abschluss als besser bzw. als komplette Remission bezeichnet; dies hielt im weiteren Verlauf häufig an (Abbildungen 2 und 3 ). In 5 (6\%) Lokalisationen bei 3 (11\%) Patienten war keine Verbesserung nach der Radiotherapie zu verzeichnen.

Schlussfolgerung: Die Ergebnisse der Bestrahlung bei palmoplantaren Ekzemen und Psoriasis sind für beide Behandlungsschemata ausgezeichnet. Wir empfehlen eine ED von 0,5 Gy und eine GD von 4-5 Gy.

Schlüsselwörter: Palmoplantare Ekzeme $\cdot$ Psoriasis $\cdot$ Radiotherapie $\cdot$ Dosis

\footnotetext{
${ }^{1}$ Institute of Radiation Oncology, State Hospital, Aarau, Switzerland,

${ }^{2}$ Department of Dermatology, State Hospital, Aarau, Switzerland.
}

Received: July 16, 2007; accepted: January 16, 2008 


\section{Introduction}

Eczema and psoriasis are common skin disorders affecting $1-5 \%$ of the adult population $[17,20]$. Due to an often chronic natural history they represent a major cause of morbidity and disability $[18,20,30]$. In general there is no evidence from large, prospective randomised studies with long-term followup for the 3 current treatment options - topical corticosteroids, topical coal tar and PUVA/UVB [3, 20, 30]. For therapy-refractory disease radiotherapy (RT) is well accepted [22], despite insufficient evidence for a comparative advantage of irradiation compared to the above mentioned treatment modalities.

Randomized controlled trials regarding RT ( 6 in palmar eczema, 1 in plantar eczema and 2 for palmo-plantar psoriasis, Table 1) do not fulfill current standards: they included low number of patients (14-30 patients) with a follow-up of only 1.3-6 months. Furthermore, the optimal irradiation dose is unknown [10, 28].

The aim of this study was to evaluate the clinical longterm outcome of RT with two different treatment policies according to RT dose for patients with palmar and/or plantar eczema or psoriasis.

\section{Patients and Methods}

Between June 1998 and July 200434 consecutive patients were referred for RT from the Department of Dermatology due to chronic palmar and/or plantar eczema or psoriasis. 6 patients were not treated due to patient refusal. 28 patients (14 female;
14 male) received radiotherapy $(\mathrm{RT})$ for eczema $(\mathrm{n}=22)$ or psoriasis $(n=6)$. Median age was 52 years (range: $27-71$ years). Before the referral to our institute patients were treated with different regimens. The median disease duration before RT was 84 months (range: 7-243 months).

The median number of regions to be irradiated was 2 (range: $1-10$ regions) per patient, resulting in totally 88 regions. All patients received orthovoltage irradiation either with $43 \mathrm{kV}$ (with Dermopan in 11 patients) or $50 \mathrm{kV}$ (with Therapax in 17 patients).

Until May 2003 a single dose of $1 \mathrm{~Gy}\left(\mathrm{D}_{\max }\right)$ twice a week was used for 49 regions, and the median total dose was $12 \mathrm{~Gy}$ (range: 7-13 Gy), whereas afterwards our treatment policy was changed and consisted of $0.5 \mathrm{~Gy}\left(\mathrm{D}_{\max }\right)$ single dose twice a week for 39 regions up to a median total dose of 5 Gy (range: 2.5-8 Gy). Examinations were always done by both, a radiation oncologist (MN) and dermatologist (PI) according to a prospectively designed score, which was generated due to following symptoms (Table 2): itching, pain, impairment of mobility, psychosocial burden, redness, hyperkeratosis, scaling and cracks. Each symptom was divided into 4 groups ranging from none (grade 0) up to severe (grade 3 ) in addition to mild or moderate symptoms (grade 1 or 2 , respectively). Each treatment location $(\mathrm{n}=88)$ was analyzed according to above mentioned categories with a score from $0-3$, giving a sum score for all eight parameters (minimum to maximum score points: 0-24). Complete remission was defined by a sum score of 0 .

Table 1. Randomized controlled trials in palmo-plantar eczema and psoriasis.

Tabelle 1. Randomisierte kontrollierte Studien zur Radiotherpie der palmoplantaren Ekzeme und Psoriasis.

\begin{tabular}{|c|c|c|c|c|}
\hline Authors & $\begin{array}{l}\text { No. of } \\
\text { Patients }\end{array}$ & $\begin{array}{l}\text { Follow-up } \\
\text { in months* }\end{array}$ & $\begin{array}{l}\text { Experimental and } \\
\text { control treatments }\end{array}$ & Results \\
\hline \multicolumn{5}{|l|}{ Eczema } \\
\hline Fairris GM, et al. 1985 [6] & 25 & 3 & $\begin{array}{l}50 \mathrm{kV}, 3 \times 1 \mathrm{~Gy} \text { vs. } 10 \mathrm{kV}, 3 \times 3 \mathrm{~Gy} \\
\text { every } 3 \text { weeks }\end{array}$ & $\begin{array}{l}\text { X-ray statistically significant better than grenz- } \\
\text { ray } 3,6 \text { and } 12 \text { weeks after start of treatment } \\
\text { not more } 18 \text { weeks }\end{array}$ \\
\hline Fairris GM, et al. 1984 [7] & 14 & 3 & 50 kV, $3 \times 1$ Gy vs. $3 \times$ placebo every 3 weeks & RT better than placebo but not significant \\
\hline Fairris GM, et al. 1984 [9] & 23 & 3 & 50 kV, $3 \times 1$ Gy vs. $3 \times$ placebo every 3 weeks & $\begin{array}{l}\text { RT significant better than placebo, especially } \\
\text { after } 6 \text { and } 9 \text { weeks }\end{array}$ \\
\hline Lindelof B, et al. 1987 [16] & 24 & 1.3 & 10 kV, $6 \times 3$ Gy vs. $6 \times$ placebo every week & Grenz-ray better than placebo after 5 weeks \\
\hline King CM, et al. 1984 [14] & 15 & 6 & 45 kV, $3 \times 1$ Gy vs. $3 \times$ placebo every week & $\begin{array}{l}\text { RT better significant after } 1 \text { month, but no more } \\
\text { significant after } 3 \text { and } 6 \text { months }\end{array}$ \\
\hline $\begin{array}{l}\text { Sheehan-Dare RA, et al. } \\
1989 \text { [27] }\end{array}$ & 21 & 3 & $\begin{array}{l}50 \mathrm{kV}, 3 \times 0.9 \text { Gy every } 3 \text { weeks vs. } \\
\text { photochemotherapy for } 6 \text { weeks, } 3 \times \text { a week }\end{array}$ & $\begin{array}{l}\text { RT significant better in the } 6 \text { th week of treatment } \\
\text { but no more } 3 \text { and } 12 \text { weeks after treatment }\end{array}$ \\
\hline $\begin{array}{l}\text { Cartwright } \mathrm{PH} \text {, et al. } \\
1987 \text { [2] }\end{array}$ & $\begin{array}{l}\text { unknown } \\
\text { (less than } \\
\text { 30) }\end{array}$ & 3 & 10 kV, $3 \times 3$ Gy vs. $3 \times$ placebo, every 3 weeks & Grenz-ray not better than placebo \\
\hline \multicolumn{5}{|l|}{ Psoriasis } \\
\hline Fairris GM, et al. 1984 [8] & 6 & 3 & 50 kV, $3 \times 1$ Gy vs. placebo every 3 weeks & $\begin{array}{l}\text { Only one patient benefit, RT has little or no } \\
\text { therapeutic effect upon palmoplantar psoriasis }\end{array}$ \\
\hline Lindelof B, et al. 1990 [15] & 15 & 1.7 & 10 kV, 6 × 4 Gy vs. placebo every week & $\begin{array}{l}\text { RT significant better than placebo but the } \\
\text { response was moderate }\end{array}$ \\
\hline
\end{tabular}

*Time between the end of treatment and last control 
The score for each symptom as well as the sum score was documented at baseline before RT, at the end of RT and at last follow-up.

Statistical comparisons between the situation before irradiation and at last follow-up were done by the Mann-Whitney

Table 2. Score of evaluated symptoms.

Tabelle 2. Einteilung evaluierter Krankheitssymptome.

\begin{tabular}{|c|c|c|c|c|}
\hline $\begin{array}{l}\text { Score } \\
\text { Score-points }\end{array}$ & $\begin{array}{l}\text { Grade } 0 \\
0\end{array}$ & $\begin{array}{l}\text { Grade } 1 \\
1\end{array}$ & $\begin{array}{l}\text { Grade } 2 \\
2\end{array}$ & $\begin{array}{l}\text { Grade } 3 \\
3\end{array}$ \\
\hline Itching & None & Rare and/or mild & $\begin{array}{l}\text { Often but mild } \\
\text { or rare but } \\
\text { intense }\end{array}$ & $\begin{array}{l}\text { Allways and } \\
\text { intense }\end{array}$ \\
\hline Pain & None & Only by movement & $\begin{array}{l}\text { Spontaneous, } \\
\text { analgetics not } \\
\text { necessary }\end{array}$ & $\begin{array}{l}\text { Spontaneous, } \\
\text { intense, analgetics } \\
\text { necessary }\end{array}$ \\
\hline $\begin{array}{l}\text { Impairment of } \\
\text { mobility }\end{array}$ & None & Mild & $\begin{array}{l}\text { Moderate, no work } \\
\text { disability, no } \\
\text { relieving posture }\end{array}$ & $\begin{array}{l}\text { Severe, work } \\
\text { disability, relieving } \\
\text { posture }\end{array}$ \\
\hline Psychosocial burden & None & Mild & Moderate & Severe \\
\hline Redness & None & Mild & Moderate & Severe \\
\hline Hyperkeratosis & None & Mild & Moderate & Severe \\
\hline Scaling & None & Mild & Moderate & Severe \\
\hline Cracks & None & $\begin{array}{l}\text { Few, small, without } \\
\text { bleeding }\end{array}$ & $\begin{array}{l}\text { Moderate, between } \\
1 \text { and } 3\end{array}$ & $\begin{array}{l}\text { Many, deep, } \\
\text { with bleeding }\end{array}$ \\
\hline
\end{tabular}

U-test. In addition patients were asked about their personal rating of RT response according to four possible groups: worse, stable, better and no symptoms (= complete remission).

The median follow-up (defined from the end of RT till last control) was 20 months (range: 4-76 months).

\section{Results}

As shown in Figure 1 and in Table 3 all patients were symptomatic before RT, most of them with a high sum score (median: 15; range: 6-23). Most common grade 3 symptoms were severe itching (69\% of all regions) and intense pain ( $73 \%$ of all regions): Severe impairment of mobility and severe psychosocial burden were reported in $42 \%$ and $38 \%$. Other symptoms like redness, hyperkeratosis, scaling and cracks were reported in $20 \%$ as grade 3 . Only $5 \%$ of regions were free of pain, other symptoms were absent in 6-26\%.

At the end of RT the median sum score was 2 (range: 0-16), and 20\% experienced complete remission (sum score of 0 ).

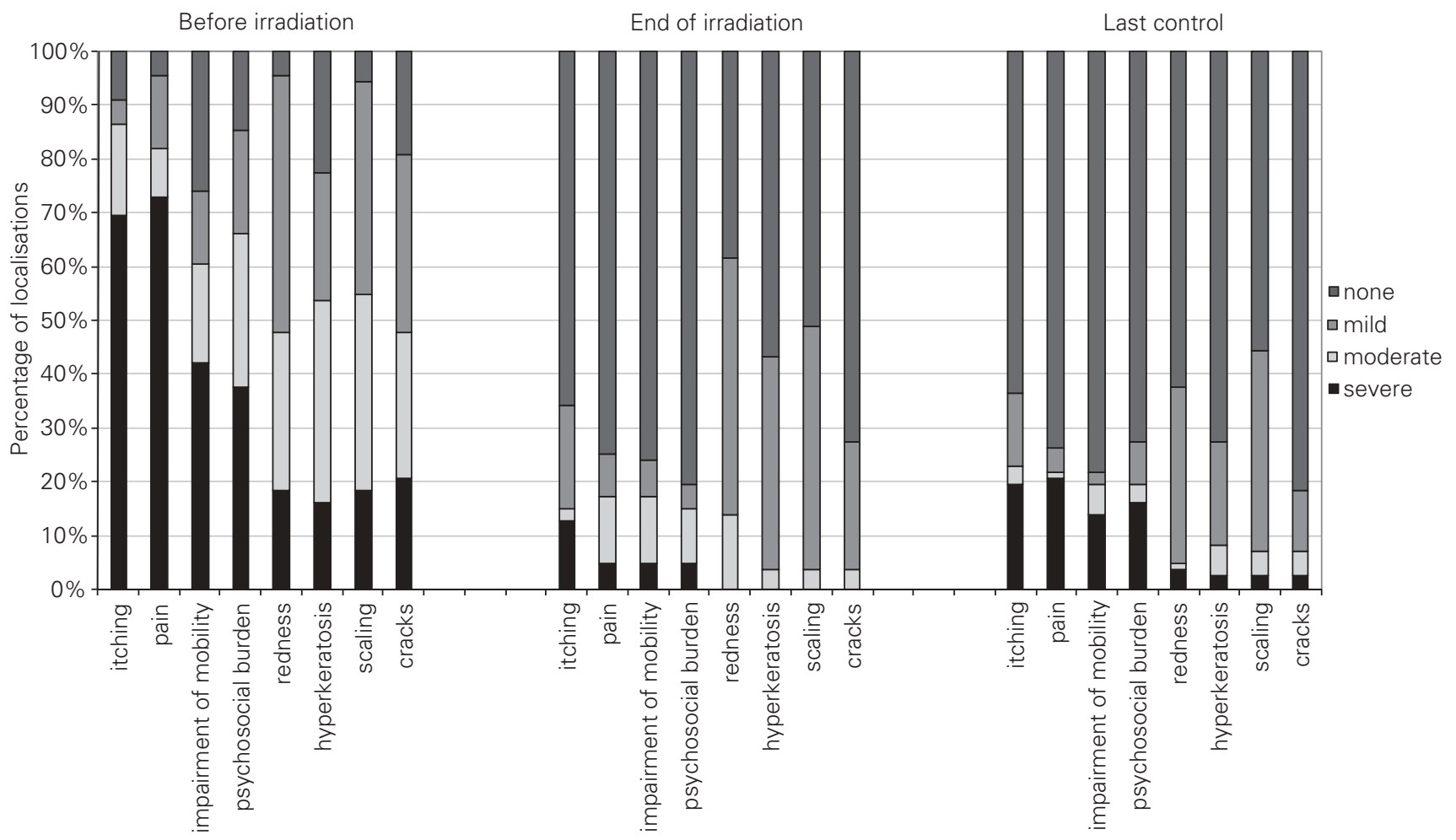

Figure 1. Severity of symptoms before and after radiotherapy and at last control (see also Table 2).

Abbildung 1. Ausprägung der einzelnen Symptome vor und nach Radiotherapie sowie bei der letzten Nachkontrolle (siehe auch Tabelle 2). 
At last control the median sum score was 1 (range: $0-21$ ), and 36\% had complete remission (Table 3, Figures 2 and 3). RT had a similar impact on each symptom (Figure 1). The differences compared to the situation before RT were highly significant (Table 3 ).

There was no marked difference between single doses of 0.5 Gy (median total dose of $5 \mathrm{~Gy}$ ) and $1 \mathrm{~Gy}$ (median total dose of $12 \mathrm{~Gy}$ ): the median sum score for both groups was 15 vs. 14 before RT, 2 vs. 2 at the end of RT and 0 vs. 2 at last control, respectively (Table 4). A significant improvement could be documented in both treatment groups.

According to patients' reports initial symptoms were rated stable at the end of RT in 5 out of 88 regions ( 3 out of 28 patients), better in 44 regions, and 39 regions were reported as complete remission. At last follow-up complete remission was reported for 32 regions (28 out of the "complete remission" group and 4 out of the "better" group at the end of RT). All 5 with stable symptoms at the end of RT remained unchanged at last follow-up (Figure 1). No region was rated worse by the patients, neither at the end of RT nor at last control.

We did not see any side effects due to radiotherapy.

\section{Discussion}

There is a long history for irradiation in benign diseases [25, 29]. First treatments by RT for chronic eczema and psoriasis were described in 1898 [11, 24]. Over decades the indication for RT in benign diseases was well accepted. In 1925 more pages were given to describing RT indications of various benign diseases than for cancer in the most comprehensive textbook for RT of that time [19]. The use of RT has decreased considerably as reports about carcinogenesis due to ionizing irradiation $[1,4]$ and new and better systemic and topical treatments have become available. However, e.g. in eczema and psoriasis of palms and soles RT is still a valid option after other therapeutic methods have failed [22].

The efficacy of RT in chronic eczema and psoriasis is supported by the re-
Table 3. Severity of symptoms for all 88 localisations before and after radiotherapy and at last control (score-points according to Table 2).

Tabelle 3. Ausprägung der einzelnen Symptome für alle 88 Lokalisationen vor und nach Radiotherapie sowie bei der letzten Nachkontrolle (Score-Punkte gemäß Tabelle 2).

\begin{tabular}{|c|c|c|c|c|c|c|c|c|}
\hline \multirow{2}{*}{$\begin{array}{l}\text { Symptom } \\
\text { Itching }\end{array}$} & \multirow{2}{*}{$\begin{array}{l}\begin{array}{l}\text { Score } \\
\text { points }\end{array} \\
0\end{array}$} & \multicolumn{2}{|c|}{$\begin{array}{l}\text { Before irradiation } \\
n=88 \quad \%\end{array}$} & \multicolumn{2}{|c|}{$\begin{array}{l}\text { End of irradiation } \\
\mathrm{n}=88 \quad \%\end{array}$} & \multicolumn{2}{|c|}{ Last control } & $p$-value* \\
\hline & & 8 & 9 & 58 & 66 & 56 & 64 & $<0.0001$ \\
\hline & 1 & 4 & 5 & 17 & 19 & 12 & 14 & \\
\hline & 2 & 15 & 17 & 2 & 2 & 3 & 3 & \\
\hline & 3 & 61 & 69 & 11 & 13 & 17 & 19 & \\
\hline \multirow[t]{4}{*}{ Pain } & 0 & 4 & 5 & 66 & 75 & 65 & 74 & $<0.0001$ \\
\hline & 1 & 12 & 14 & 7 & 8 & 4 & 5 & \\
\hline & 2 & 8 & 9 & 11 & 13 & 1 & 1 & \\
\hline & 3 & 64 & 73 & 4 & 5 & 18 & 20 & \\
\hline \multirow{4}{*}{$\begin{array}{l}\text { Impairment } \\
\text { of mobility }\end{array}$} & 0 & 23 & 26 & 67 & 76 & 69 & 78 & $<0.0001$ \\
\hline & 1 & 12 & 14 & 6 & 7 & 2 & 2 & \\
\hline & 2 & 16 & 18 & 11 & 13 & 5 & 6 & \\
\hline & 3 & 37 & 42 & 4 & 5 & 12 & 14 & \\
\hline \multirow{4}{*}{$\begin{array}{l}\text { Psychosocial } \\
\text { burden }\end{array}$} & 0 & 13 & 15 & 71 & 81 & 64 & 73 & $<0.0001$ \\
\hline & 1 & 17 & 19 & 4 & 5 & 7 & 8 & \\
\hline & 2 & 25 & 28 & 9 & 10 & 3 & 3 & \\
\hline & 3 & 33 & 38 & 4 & 5 & 14 & 16 & \\
\hline \multirow[t]{4}{*}{ Redness } & 0 & 4 & 5 & 34 & 39 & 55 & 63 & $<0.0001$ \\
\hline & 1 & 42 & 48 & 42 & 48 & 29 & 33 & \\
\hline & 2 & 26 & 30 & 12 & 14 & 1 & 1 & \\
\hline & 3 & 16 & 18 & 0 & 0 & 3 & 3 & \\
\hline \multirow[t]{4}{*}{ Hyperkeratosis } & 0 & 20 & 23 & 50 & 57 & 64 & 73 & $<0.0001$ \\
\hline & 1 & 21 & 24 & 35 & 40 & 17 & 19 & \\
\hline & 2 & 33 & 38 & 3 & 3 & 5 & 6 & \\
\hline & 3 & 14 & 16 & 0 & 0 & 2 & 2 & \\
\hline \multirow[t]{4}{*}{ Scaling } & 0 & 5 & 6 & 45 & 51 & 49 & 56 & $<0.0001$ \\
\hline & 1 & 35 & 40 & 40 & 45 & 33 & 38 & \\
\hline & 2 & 32 & 36 & 3 & 3 & 4 & 5 & \\
\hline & 3 & 16 & 18 & 0 & 0 & 2 & 2 & \\
\hline \multirow[t]{4}{*}{ Cracks } & 0 & 17 & 19 & 64 & 73 & 72 & 82 & $<0.0001$ \\
\hline & 1 & 29 & 33 & 21 & 24 & 10 & 11 & \\
\hline & 2 & 24 & 27 & 3 & 3 & 4 & 5 & \\
\hline & 3 & 18 & 20 & 0 & 0 & 2 & 2 & \\
\hline
\end{tabular}

${ }^{*}$ p-values are given for each symptom at last control compared to the situation before irradiation.
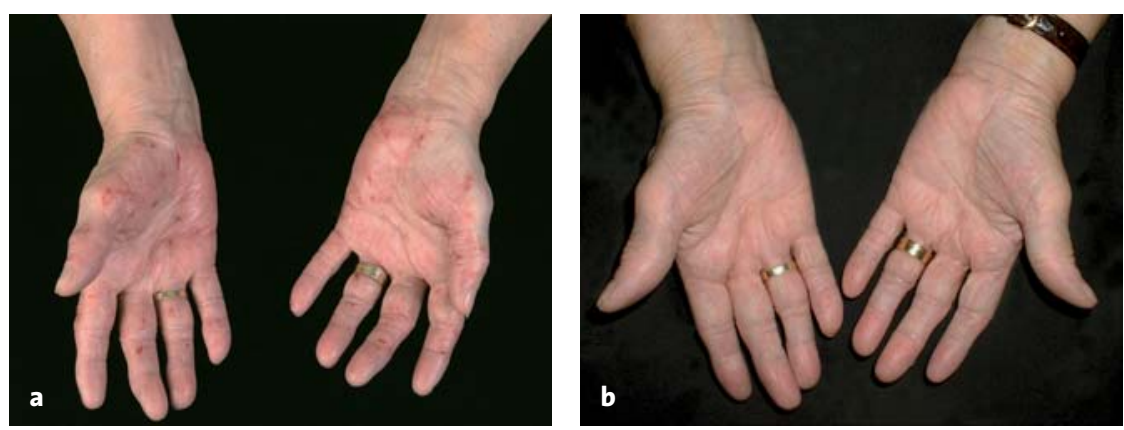

Figure 2. Chronic hand eczema in a 67-year-old woman before (a) and 8 month after radiotherapy (b): total dose $4 \mathrm{~Gy}$ in eight fractions, delivered twice per week, $50 \mathrm{kV}$.

Abbildung 2. Chronisches Handekzem bei einer 67-jähriger Patientin, vor (a) und 8 Monate nach Radiotherapie (b): Gesamtdosis 4 Gy in acht Fraktionen, zweimal pro Woche, 50 kV. 
sults of randomized trials, all of them were performed in the eighties (Table 1). According to current standards they hardly fulfill criteria for evidence-based medicine [3, 20,30]. They included low numbers of patients and follow-up was only 5 weeks to 6 months (median 4 months). Therefore outcome

Table 4. Changes of sum-score for all 88 localisations (bold) and for the subgroups treated with a single dose (SD) of 0.5 Gy and 1.0 Gy.

Tabelle 4. Änderungen des Summen-Scores bezogen auf alle 88 bestrahlten Lokalisationen (fett) mit Berücksichtigung der Untergruppen mit Einzeldosen (SD) von 0.5 Gy bzw. 1 Gy.

\begin{tabular}{|c|c|c|c|c|c|c|}
\hline $\begin{array}{l}\text { Sum- } \\
\text { score }\end{array}$ & $\begin{array}{l}\text { Before irrad } \\
n=88 \\
S D: 0.5 \mathrm{~Gy} \\
n=39\end{array}$ & $\begin{array}{l}\text { iation } \\
\text { SD: } 1.0 \mathrm{~Gy} \\
\mathrm{n}=49\end{array}$ & $\begin{array}{l}\text { End of irrad } \\
n=88 \\
S D: 0.5 \mathrm{~Gy} \\
n=39\end{array}$ & $\begin{array}{l}\text { ation } \\
\text { SD: } 1.0 \text { Gy } \\
n=49\end{array}$ & $\begin{array}{l}\text { Last control } \\
n=88 \\
S D: 0.5 \mathrm{~Gy} \\
\mathrm{n}=39\end{array}$ & $\begin{array}{l}\text { SD: } 1.0 \mathrm{~Gy} \\
\mathrm{n}=49\end{array}$ \\
\hline \multirow[t]{2}{*}{0} & \multicolumn{2}{|l|}{0} & \multicolumn{2}{|l|}{18} & \multicolumn{2}{|l|}{32} \\
\hline & 0 & 0 & 11 & 7 & 21 & 11 \\
\hline \multirow[t]{2}{*}{$1-4$} & \multicolumn{2}{|l|}{0} & \multicolumn{2}{|l|}{48} & \multicolumn{2}{|l|}{31} \\
\hline & 0 & 0 & 21 & 27 & 7 & 24 \\
\hline \multirow[t]{2}{*}{$5-8$} & \multicolumn{2}{|l|}{4} & \multicolumn{2}{|l|}{7} & \multicolumn{2}{|l|}{3} \\
\hline & 4 & 0 & 1 & 6 & 0 & 3 \\
\hline \multirow[t]{2}{*}{$9-12$} & \multicolumn{2}{|l|}{22} & \multicolumn{2}{|l|}{8} & \multicolumn{2}{|l|}{11} \\
\hline & 7 & 15 & 3 & 5 & 5 & 5 \\
\hline \multirow[t]{2}{*}{$13-16$} & \multicolumn{2}{|l|}{30} & \multicolumn{2}{|l|}{7} & \multicolumn{2}{|l|}{9} \\
\hline & 14 & 16 & 3 & 4 & 6 & 3 \\
\hline \multirow[t]{2}{*}{$17-20$} & \multicolumn{2}{|l|}{24} & \multicolumn{2}{|l|}{0} & \multicolumn{2}{|l|}{1} \\
\hline & 8 & 16 & 0 & 0 & 0 & 1 \\
\hline \multirow[t]{2}{*}{$21-24$} & \multicolumn{2}{|l|}{8} & \multicolumn{2}{|l|}{0} & \multicolumn{2}{|l|}{2} \\
\hline & 6 & 2 & 0 & 0 & 0 & 2 \\
\hline \multirow[t]{2}{*}{ Median } & \multirow{2}{*}{\multicolumn{2}{|c|}{$15(6-23)$}} & \multicolumn{2}{|c|}{$2(0-16)$} & \multicolumn{2}{|c|}{$1(0-21)$} \\
\hline & & & & & $p<0.000$ & $01^{*}$ \\
\hline \multirow[t]{2}{*}{ (range) } & \multirow[t]{2}{*}{$15(6-23)$} & \multirow[t]{2}{*}{$14(9-21)$} & \multirow[t]{2}{*}{$2(0-16)$} & $2(0-15)$ & $0(0-16)$ & $2(0-21)$ \\
\hline & & & & & $p<0.0001^{*}$ & $p<0.0001^{*}$ \\
\hline
\end{tabular}

${ }^{*}$ compared to the situation before irradiation
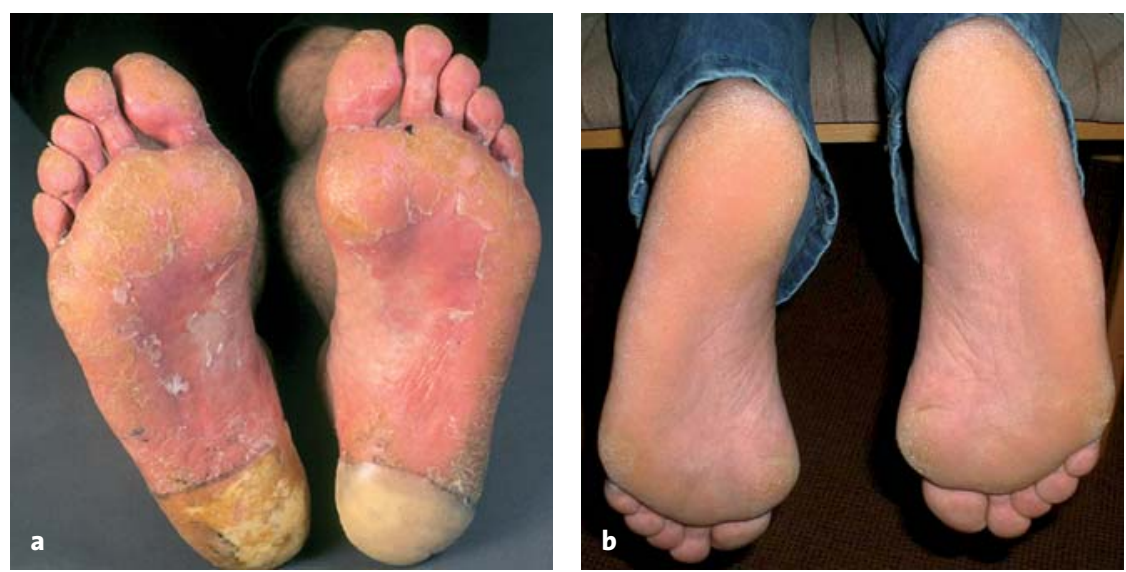

Figure 3. Palmoplantar psoriasis in a 52-year-old man before (a) and 14 months after radiotherapy (b): total dose 6 Gy in twelve fractions, delivered twice per week, $50 \mathrm{kV}$.

Abbildung 3. Psoriasis palmoplantaris bei einem 52-jährigen Patienten, vor (a) und 14 Monate nach Radiotherapie (b): Gesamtdosis 6 Gy in zwölf Fraktionen, zweimal pro Woche, 50 kV. in the mid or long term is unknown. Severity-scores for symptoms were different and simplified encompassing several symptoms. Due to the absence of accepted severity-scores in both eczema and psoriasis [5, 20, 30, 31] a comparison of trials is difficult. Regarding RT single doses of 0.9 Gy -4 Gy and total doses of $2.7 \mathrm{~Gy}-24 \mathrm{~Gy}$ were used in these trials. Unfortunately newer data are lacking.

Our study revealed several interesting findings: We have scored 8 different symptoms, and there was a marked reduction of severity in each symptom at the end of RT, which was quite stable till last follow-up. These improvements were highly significant.

Complete remission (CR) and improvement of symptoms were seen for a high proportion of treated areas at the end of RT according to patients' rating. $\mathrm{CR}$ and improvement were documented for almost all regions $(39+44=83$ out of 88 ), which remained stable in 68 areas (32 with $\mathrm{CR}$ and 36 with improvement) at last follow-up. On the other hand, the remaining 5 regions (3 patients) without change at the end of RT showed no improvement also during the follow-up.

Doctors' rating revealed also excellent results: CR (sum-score: 0 ) or nearly CR (sum-score: 1-4) was documented for $18+48=66$ out of 88 regions at the end of RT, and for $32+31=63$ out of 88 regions at last follow-up.

We could not see major differences between lower and higher doses of RT, both treatment schedules revealed highly significant rates of improvement. This is in accordance with the literature on irradiation in benign diseases $[13,23$, overviews in 10 and 28]. The only systematic dose-finding study was performed on more than 500 localisations with eczema or psoriasis, and there was no difference between 0.6 Gy, $0.8 \mathrm{~Gy}$ and $1 \mathrm{~Gy}$ [10]. In a recent overview by Panizzon [22] single doses of $0.3 \mathrm{~Gy}$ to $1 \mathrm{~Gy}$ and total doses of 3 Gy to 12 Gy are recommended for inflammatory diseases including eczema and psoriasis.

The excellent results are in part different in comparison with previous published studies summarized in Table 1. There is no obvious reason for that, however findings among randomized studies 
are also inconsistent. A well conducted randomized study should be performed to show that radiotherapy might be an ideal treatment option for resistant cases to topical and physical treatments. Similar to other nonmalignant diseases [12, 21, 26] undertaking of a pattern of care study would be also desirable in palmoplantar eczema and psoriasis. It would be interesting to see how many radiotherapy centers actually treat chronic palmo-plantar eczema or psoriasis, and with which technique and dose. The potential risk of irradiation of a benign, non-life-threatening disease must be recognised. However, regarding the very low risk of radiation-induced cancer RT may be considered if other methods have not succeeded and if the consequences of no further treatment are unacceptable for the patient.

\section{Conclusion}

Topical steroids are the mainstay of the pharmacological treatment of palmo-plantar eczema and psoriasis. For patients with otherwise therapy-refractory eczema or psoriasis RT offers high rates of improvement or complete remission, which can last several years. RT should be taken into consideration in these patients. Both treatment regimens, low and higher dose irradiation, had highly significant improvement rates. Therefore, we propose a single dose of $0.5 \mathrm{~Gy}$, twice a week, to a total dose of max. $5 \mathrm{~Gy}$.

\section{References}

1. Cannon B, Randolph JS, Murray JE. Malignant irradiation for benign conditions. N Engl J Med 1959; 260:197-20.

2. Cartwright PH, Rowell NR. Comparison of Grenz rays versus placebo in the treatment of chronic hand eczema. Br J Dermatol 1987;117:73-6.

3. Coenraads PJ, van Coevorden AM, Diepgen TL. Hand eczema. In: Williams HC, Bigby M, Diepgen TL, et al. (eds.). Evidence-based Dermatology, London: BML Books, 2003:132-43.

4. Court-Brown WM, Doll R. Mortality from cancer and other causes after radiotherapy for ankylosing spondylitis. Brit Med J 1965:1327-32.

5. Diepgen TL, Svensson A, Coenraads PJ. Therapie von Handekzemen. Was können wir von publizierten klinischen Studien lernen? Hautarzt 2005; 56:224-31.

6. Fairris GM, Jones DH, Mack DP, Rowell NR. Conventional superficial X-ray versus Grenz ray therapy in the treatment of constitutional eczema of the hands. Br J Dermatol 1985;112:339-41.

7. Fairris GM, Jones DH, Mack DP, Rowell NR. Superficial X-ray therapy in the treatment of constitutional eczema of the feet. Br J Dermatol. 1984; 111:500-2.

8. Fairris GM, Jones DH, Mack DP, Rowell NR. Superficial X-ray therapy in the treatment of palmoplantar pustulosis. Br J Dermatol. 1984;111:499-500.

9. Fairris GM, Mack DP, Rowell NR. Superficial X-ray therapy in the treatment of constitutional eczema of the hands. Br J Dermatol. 1984;111:4459.

10. Goldschmidt H, Yawalkar S, Gruber L, Schirren CG. Experimentelle Untersuchungen zur Weichstrahldosierung bei Ekzem und Psoriasis. Strahlentherapie 1962;118:240-9.

11. Hahn R. Durch Röntgenstrahlen geheiltes chronisches Ekzem. Wien Med Wochenschr 1898:2005.

12. Heyd R, Seegenschmiedt MH, Strassmann G, et al. German Cooperative Group on Radiotherapy for Benign Diseases (GCG-BD). Radiotherapy for Graves' orbitopathy: results of a national survey. Strahlenther Onkol. 2003;179:372-6.
13. Heyd R, Tselis N, Ackermann H, et al. Radiation Therapy for Painful Heel Spurs: Results of a Prospective Randomized Study. Strahlenther Onkol. 2007:183:3-9.

14. King CM, Chalmers RJ. A double-blind study of superficial radiotherapy in chronic palmar eczema. Br J Dermatol. 1984:111:451-4.

15. Lindelof $B$, Beitner $H$. The effect of grenz ray therapy on pustulosis palmoplantaris. A double-blind bilateral trial. Acta Derm Venereol 1990; 70:529-31.

16. Lindelof $B$, Wrangsjo K, Liden S. A double-blind study of Grenz ray therapy in chronic eczema of the hands. Br J Dermatol 1987;117:77-80.

17. Meding B. Epidemiology of hand eczema in an industrial city. Acta Derm Venereol Suppl (Stockh). 1990;153:1-43.

18. Meding B, Wrangsjo K, Jarvholm B. Fifteen-year follow-up of hand eczema: persistence and consequences. Br J Dermatol 2005;152:975-80.

19. Meyer H. Lehrbuch der Strahlentherapie, 4 vol. Berlin - Wien: Urban \& Schwarzenberg 1925.

20. Naldi L, Svensson A, Diepgen T, et al. European Dermato-Epidemiology Network. Randomized Clinical Trials for Psoriasis 1977-2000: The EDEN Survey. J Invest Dermatol 2003;120:738-41.

21. Olschewski T, Seegenschmiedt MH. Radiotherapy of Langerhans' Cell Histiocytosis: Results and Implications of a National Patterns-of-Care Study. Strahlenther Onkol. 2006;182:629-34.

22. Pannizon RG. Radiation Therapy of Benign Dermatoses. In: Pannizon RG, Cooper JS (eds.). Radiation Treatment and Radiation Reactions in Dermatology, Berlin-Heidelberg: Springer 2004:33-40.

23. Rades D, Schild SE. Is $50 \mathrm{~Gy}$ sufficient to achieve long-term local control after incomplete resection of typical neurocytomas? Strahlenther Onkol. 2006;182:415-8.

24. Schmitz R. Zur geschichtlichen Entwicklung der Röntgentherapie in der Dermatologie. Strahlentherapie. 1950;82:401-18.

25. Schultze J, Elif K. Perspectives of radation therapy in benign diseases. Strahlenther Onkol 2006;182:250-62.

26. Seegenschmiedt MH, Micke 0 , Willich N. Radiation therapy for nonmalignant diseases in Germany. Current concepts and future perspectives. Strahlenther Onkol. 2004 Nov; 180:718-30.

27. Sheehan-Dare RA, Goodfield MJ, Rowell NR. Topical psoralen photochemotherapy (PUVA) and superficial radiotherapy in the treatment of chronic hand eczema. Br J Dermatol 1989;121:65-9.

28. Trott KR. Therapeutic effects of low radiation doses. Strahlenther Onkol. 1994:170:1-12.

29. Trott KR, Kamprad F. Estimation of cancer risks from radiotherapy of benign diseases. Strahlenther Onkol 2006;182:431-6.

30. Van Coevorden AM, Coenraads PJ, Svensson A, et al. Overview of studies of treatments for hand eczema - the EDEN hand eczema survey. Br J Dermatol 2004;151(2):446-5.

31. Vocks E, Plotz SG, Ring J. The Dyshidrotic Eczema Area and Severity Index - A score developed for the assessment of dyshidrotic eczema. Dermatology 1999;198:265-9.

\author{
Address for Correspondence \\ Guenther Gruber, MD \\ Institute of Radiotherapy \\ Klinik Hirslanden \\ Witellikerstrasse 40 \\ 8032 Zuerich \\ Switzerland \\ Phone: (+41/44) 38725-50, Fax -51 \\ e-mail:guenther.gruber@hirslanden.ch
}

